STAYING SOBER IN MEXICO CITY 
THIS PAGE INTENTIONALLY LEFT BLANK 


\section{STAYING \\ SOBER IN}

MEXICO

CITY

Stanley Brandes

$\checkmark v$ The University of Texas Press 
Copyright $(\odot 2002$ by the University of Texas Press

All rights reserved

Printed in the United States of America

First edition, 2002

Requests for permission to reproduce material from this work should be sent to Permissions, University of Texas Press, Box 78 I9, Austin, TX 78713-78г9.

(2) The paper used in this book meets the minimum requirements of ANSI/NISO Z39.48-I992 (RI997) (Permanence of Paper).

Library of Congress Cataloging-in-Publication Data

Brandes, Stanley H.

Staying sober in Mexico City / Stanley Brandes.—Ist ed.

p. $\mathrm{cm}$.

Includes bibliographical references and index.

ISBN 0-292-70905-6 (alk. paper)-

ISBN 0-292-70908-O (alk. paper)

I. Alcoholics Anonymous-Case studies. 2. Twelve-step programs-Mexico-Mexico City-Sociological aspects.

3. Alcoholics-Rehabilitation-Mexico-Mexico City.

4. Recovering alcoholics-Mexico-Mexico City. I. Title.

$\mathrm{HV} 5283 . \mathrm{M} 62 \mathrm{M} 483 \quad 2002$

$362.292^{\prime} 86^{\prime} 092-\mathrm{dc} 2 \mathrm{I}$

[B]

2001048063 
Para mis compañeros 
THIS PAGE INTENTIONALLY LEFT BLANK 